\title{
The Medium and the Message
}

\section{The Public Destruction of Books and Documents in the European Middle Ages}

In modern times, writing is very common and most of it is ephemeral. Its destruction is therefore largely a matter of routine. In the Middle Ages, however, things were different. Writing was less common and much of it was intended to be preserved for posterity. As Michael Clanchy has shown, medieval scribes were essentially presented with the alternatives of wax or parchment as a writing surface. They therefore had to make an initial choice between what was transitory and ephemeral, and what was permanent and worth remembering. To write a text on a durable material such as parchment was, in other words, "to make a lasting memorial". ${ }^{1}$ But like any other object, from the very moment of its production each and every medieval book or document was exposed to a whole range of dangers. It could decay over time (wear and tear, humidity, insects ...), or perish in all kinds of calamities (fires, floods, wars, looting ...), or simply be lost as a consequence of neglect. And it could also be deliberately destroyed. The wilful destruction of a text involves either destroying its physical support, or effacing its script, or damaging it in such a way that it can no longer be used. ${ }^{2}$ This could be done in a great variety of ways, which can be roughly divided into four categories:

1. the physical destruction of the object, thus affecting both the text and the material it was written on: manuscripts and documents could be burnt, cut up, or torn to pieces; ${ }^{3}$

2. the destruction of the text only: writing might be effaced by erasure or by washing off the ink;

3. the impairment of the text in order to make it illegible or at least unfit for use: writing could be deleted or crossed out;

4. the symbolic 'destruction' or damaging of the object, leaving the writing material and the text largely intact: documents could be legally invalidated or cancelled by making incisions in the parchment, or by breaking the seal(s).

1 Clanchy 1993, 145.

2 Cf. Mauntel et al. 2015.

3 Sources often mention charters that were torn to pieces. Parchment was, however, a quite strong material; cf. Mauntel et al. 2015, 736 ("Die Aussage, eine Urkunde sei zerrissen worden, evoziert somit eine Leichtigkeit die materiell nicht gegeben war”). We may therefore assume that more often than not the physical destruction of a charter was achieved through a combination of cutting and tearing up. For an example, see Werner 2007, 88-89. 
As to the motives prompting such actual or symbolic destruction, two possibilities have to be considered: ${ }^{4}$

1. the recuperation of the writing material-in the Middle Ages this was generally parchment-either to reuse as a writing surface (a so-called palimpsest, i.e. a manuscript or document from which the original writing has been erased or washed off and which is then used again), or as bookbinding material (e.g. as pastedowns or endleaves); ${ }^{5}$

2. the destruction of the content of the book or document. ${ }^{6}$

In the first case, manuscripts and documents were seen primarily as physical objects whose material could be recycled. In the second instance, it was the texts the books and documents contained that were targeted and destroyed. This could happen both publicly or covertly, and the method of destruction could also vary greatly. Burning is certainly the most efficient way of destroying texts, and in the Middle Ages it was the preferred method of book-destruction. Documents could also be burnt, but they were more often torn to pieces or ritually cancelled by making incisions in the parchment. The public destruction of documents was often politically motivated, whereas books were generally destroyed for religious reasons. In this paper we will focus on the destruction of books and documents as texts, and particularly on their public destruction. As Marco Mostert and Anna Adamska have stressed with regard to medieval charters, there is indeed a fundamental difference between the 'public execution' of texts and the destruction of texts that occurred unwitnessed. ${ }^{7}$

The public destruction of books and documents is an act of communication, which conveys a message. ${ }^{8}$ The form of communication is therefore not unimportant, for it is the form-that is, the way in which the message is mediated-that determines the impact of the message. Marshall McLuhan encapsulated this idea in his famous dictum "the medium is the message". By this he means that each medium affects its audience differently and thus transforms the content of the message. ${ }^{9}$ Even

\footnotetext{
4 In the case of documents there is also a third possibility: some, mainly financial documents only had a temporary validity and their invalidation was foreseen from the outset; normally they would be destroyed or cancelled once the contract expired or the obligations were fulfilled (e. g. when a debt was repaid); nonetheless, many of these invalidated documents have survived because they were archived in the late Middle Ages; see Nelis 1927, 760-766; Sennis 2013, 157.

5 Declercq 2013, 138-152.

6 Declercq 2013, 129-138 and 152-160.

7 Adamska/Mostert 2006.

8 Cf. Mente 2004.

9 McLuhan 1964 (Chapter 1: 'The medium is the message'). On the meaning of this dictum, which is not a logical postulate nor an equation but rather a metaphor, see Logan 2011, 42-43 and Strate 2012. In fact the aphorism had multiple meanings for McLuhan. It should also be noted that he used the term medium unproblematically and in a broad sense. For a critical discussion of McLuhan's ideas, see Lister et al. 2009, 77-94.
} 
though McLuhan has been criticised, notably by Umberto Eco, for the ambiguity of his 'formula' and especially for the fact that he played on terms by lumping together different meanings of the word 'medium' (form, code, channel of communication), ${ }^{10}$ his memorable one-liner is nonetheless very fitting because it reminds us that the form of communication is at least as important as the content of the message. In the case of the destruction of books, the organisers of the event will try to maximise the effect and will consequently chose a form that guarantees this aim. Ripping a book to pieces in public does not have the same impact as burning a book publicly, because the latter is a ritual with a much stronger visual component. The destruction of a book by fire must therefore have had a far greater effect on those attending and on their perception of what they witnessed. Or, as Daniel Sarefield has stressed with regard to the practice in the Roman Empire, "a book burning is more than a ceremonial act, it is a spectacle that transmits forceful social and religious messages to victims, witnesses, and participants alike". ${ }^{11}$ The symbolic and ideological utility of the rite was not lost on the Church, which would appropriate the practice and perpetuate it for centuries, even though its own sacred books had been subjected to the same treatment until the early fourth century.

\section{The Burning of Books}

Ever since its official recognition in the fourth century, the Church has indeed observed a policy of repressive censorship aimed at monopolising the interpretation of Christian doctrine. In the fourth and fifth centuries the Christian emperors-starting with Constantine at the Council of Nicaea in 325-regularly ordered the burning of books condemned by the Church. ${ }^{12}$ After the disappearance of the Roman Empire in the Latin West the practice was continued by the Church itself. Throughout the Middle Ages the ecclesiastical authorities ordered the destruction of books-generally by burningbecause of content deemed heretical or unorthodox. This censorship was not yet institutionalised, however, and its application was therefore neither systematic nor continuous. It depended upon a number of factors: the zeal of certain bishops or inquisitors,

10 Eco 1998, 135-141 and 227-238. In line with his own research on 'open texts' (opera aperta), Eco attributed an important role to the receiver of the message: "The medium is not the message; the message becomes what the receiver makes of it, applying to it his own codes of reception” (p. 235). In the case of a ritual or spectacle, the question is, of course, whether the spectators understood what was happening (see Briggs/Burke 2009, 34-36), but this cannot have been a problem here, for the public destruction of a book or a document is a ritual with a clear message: the rejection of the ideas expressed in the book and the abolition of the rights contained in the document.

11 Sarefield 2007, 159; see also Sarefield 2006, 288-289. In an article on book burning in sixteenthcentury England, David Cressy argues that it was both medium and message (Cressy 2005, 361).

12 Speyer 1981, 142-157; Herrin 2009, 210-211. 
their reasons and preoccupations, the balance of power between the different actors, the regional or local circumstances, and especially the specific context of each act of censorship. Political factors or the attitude of princes or civil authorities could also have a part to play. Moreover, in most cases the ecclesiastical authorities acted only after someone had signalled or denounced an author or a particular book. In those circumstances book burning, usually carried out in public with great solemnity, should be seen above all as a deterrent, meant to frighten and intimidate. ${ }^{13}$

The books condemned and burnt by the Church in the medieval West can roughly be divided into four categories: ${ }^{14}$

1. theological or philosophical works in Latin that contained 'theses' deviating from the official doctrine;

2. religious writings in the vernacular produced and/or used by heretical movements;

3. texts relating to magic and superstition;

4. Jewish books, particularly the Talmud, which was condemned as blasphemous by Pope Gregory IX in 1239.

Before 1200 book burning was not a common occurrence, but after that date it increased considerably. Out of a total of 220 or so documented cases between 492 and 1515, the vast majority ( $85 \%$ ) date from after $1200 .{ }^{15}$ The reason appears to be twofold: on the one hand there was a significant rise in literacy from the twelfth century onwards, resulting in the production of an ever growing number of manuscripts and an increasing use of the vernacular in written texts; on the other it was at this point that the condemnation and destruction of books became one of the weapons the Church deployed in the more general struggle against heresy and heretical movements, directed principally by the Inquisition.

It was precisely because of that increasing literacy and the emergence and growing popularity of heretical movements in the late Middle Ages that the Church also distrusted religious books written in or translated into the vernacular, especially translations of the Bible. In 1200, several books translated from Latin into French-most probably the Gospels, the letters of St Paul and the Psalter-were burnt in Metz. The books had belonged to a group of so-called Waldensians, a heretical sect named after Peter Waldo, a rich moneylender who had ordered a translation of the Bible into the vernacular. The councils of Toulouse (1229) and Tarragona (1234) prohibited the possession

13 Declercq 2013, 137-138. The situation in the Middle Ages was not, in fact, different from that in the Roman Empire, where specific circumstances also determined whether prohibited books were destroyed or not; see Sarefield 2006, 290: "the active prosecution of accusations by an official committed to carrying them through to their ultimate end [...] was also necessary for bookburning to come about”.

14 Werner 2007, 31-37.

15 See the list in Werner 2007, 552-558 (before 1200) and 559-598 (after 1200). 
of translations of the Bible, and the decrees of the latter council explicitly stated that these books should be handed over to the ecclesiastical authorities for burning. ${ }^{16}$ In 1274 a theologian of Paris University, Guibert of Tournai, who had seen a translation of the Bible made for the Beguines, described such works in the vernacular as dangerous books, for they contained heresies, errors and doubtful interpretations. In his opinion, it was therefore better to burn these translations so that the heresy could be halted at its source. ${ }^{17}$ And in 1369, the German king and Holy Roman Emperor Charles IV ordered the bishops and princes of his realm to assist the Inquisition in tracking down and destroying sermons and other writings in the vernacular that were circulating in Germany among the religious movement of the Beguines and Beghards. ${ }^{18}$

As these cases show, what the Church feared most was the errors of interpretation that could result when the Scriptures were read by lay people. Thus the intention behind the condemnation and burning of Bible translations was to quash any heretical or unorthodox interpretation. The distrust of possible errors of interpretation based on an 'incorrect' reading of the Bible was in fact a much older tradition. Even a Latin text that was in itself fully canonical and orthodox could be condemned to the fire for that reason. In 849, at the synod of Quierzy, the Carolingian theologian Gottschalk of Orbais was forced to cast into the flames the anthology of excerpts from the Bible and the writings of the Fathers of the Church that he had composed. ${ }^{19}$ In this case, the error lay in the selection and combination of canonical texts that Gottschalk had read and used in an unorthodox way. Similarly, in 1059, at a synod in Rome, Berengar of Tours was condemned to burn the book of biblical and patristic quotations that he had compiled to defend his controversial views on the Eucharist. Looking back on the event, Berengar would later write: "Troubled by the approach and menace of death, I did not feel horror at casting into the fire the writings of the prophets, evangelists and apostles". ${ }^{20}$

The sources often stress that the burning took place (or should take place) publice or solemniter. ${ }^{21}$ The destruction by fire of one or more books in the context of a great assembly or in another public setting as part of a carefully staged ritual was undoubtedly a ceremony that produced a great impact. If the author was present he was publicly humiliated, and was sometimes forced not only to retract his ideas but also to throw his own work into the fire. This was the fate of Gottschalk of Orbais at Quierzy

16 De Poerck 1968, 32 and 34; cf. also Werner 2007, 559-560.

17 Verdeyen 1985, 91 and 93; see also Werner 1995, 164.

18 von Mosheim 1790, 368-375.

19 McKitterick 2004, 218-220.

20 Fargo Brown 1923, 259; cf. Werner 2007, 141.

21 See e. g. Denifle/Châtelain 1889, 107: “ubicunque ipsum vel partem eius inveniri contigerit, ad nos, si secure fieri poterit, sine dilatione mittatis solempniter comburendum, alioquin vos ipsi publice comburatis eundem" (Pope Honorius III orders the destruction of a work by the Carolingian scholar John Eriugena, 23 January 1223). 
in 849 and Berengar of Tours at Rome in 1059, as well as Peter Abelard at Soissons in 1121 and Nicolas d'Autrecourt at Paris in $1347 .^{22}$ In the late Middle Ages in particular, book burning was usually staged during a public ceremony, where the condemnation was read out and the errors and/or blasphemies on which the sentence was based were made public. ${ }^{23}$ In some cases the performance, which could include a liturgical rite (a mass and/or a procession), was quite dramatic. When in 1410 a pile of books containing works by the English heretic John Wyclif was burnt in Prague in front of the episcopal residence, the death-bell tolled ("quasi in mortuis" says a contemporary chronicler), while the clergy intoned the Te Deum. ${ }^{24}$

In modern usage, such ceremonies are known as auto-da-fé. Although this Portuguese term, derived from the Latin actus fidei, now signifies every destruction by fire, especially the burning of books and of heretics themselves, its original meaning was simply the proclamation of a sentence pronounced by the Inquisition. A medieval auto-da-fé could therefore include the burning of books, but never the execution of their authors. ${ }^{25}$ It is certainly true that from the early fourteenth century onwards authors who refused to retract their so-called errors were condemned to the stake, but this was always the work of the civil authority, to whom they were handed over once their books had been condemned and burnt by the Church. The first example is the execution of Marguerite Porete, a Beguine from Valenciennes, in Paris on 1 June 1310, a day after her book Le Miroir des simples âmes was burnt on the Place de Grève during a public ceremony presided over by the bishop. ${ }^{26}$ The best known case is that of Jan Hus, who was executed in Constance on 6 July 1415, after his writings had been condemned and burnt by the Council of Constance earlier that same day. ${ }^{27}$ The public destruction of heretical theses by fire was believed to send such a strong and essential message that it was deemed necessary even when they had never been written down but only imparted orally. In those cases, apparently, the list of errors that had been drafted to condemn their author was burnt instead. In 1418, the Council of Constance held a solemn ceremony in which Nicole Serrurier, an Augustinian preacher from Tournai, was condemned for heresy. He showed himself repentant and was pardoned. Immediately afterwards the list of condemned errors was publicly burned in front of the cathedral. ${ }^{28}$ The burning of this list of errors shows that the purpose of burning books was in fact to destroy symbolically the errors they contained. ${ }^{29}$

22 Werner 2007, 127-143 and 336-338.

23 Werner 1995, 175-181; Werner 2007, 107-126 and 478-500.

24 Goll 1893, 571; cf. Werner 2007, 333.

25 Moeller 1913, 722-726 and 733; cf. Werner 2007, 471-473.

26 Verdeyen 1985, 80-89; Werner 2007, 468-471 and 474-478; Declercq 2013, 130.

27 Werner 2007, 452-455.

28 Cauchie 1914-1920, 273-277; cf. Werner 2007, 339-344 and Werner 1995, 180.

29 Werner 2007, 343: "Ritualimmanent betrachtet, sorgte die Bücherverbrennung dafür, den Irrtum symbolisch zu liquidieren”. In 1347, Nicolas d'Autrecourt was forced to cast his own book and the list of errors into the fire (ibidem, 112-113 and 336-338). 
In the vast majority of cases, no more than a handful of copies of the condemned book were burnt at any one time. Often, only a single copy was destroyed. Moreover, no real attempt was made to track down condemned books, ${ }^{30}$ and the decrees ordering those possessing such books to hand them in at short notice generally remained a dead letter. The intention may well have been there, but the Church simply did not have the means to enforce its decrees and there was no strong secular power either that could have supported its claims. ${ }^{31}$ The burning of a heretical or heterodox work therefore had a largely symbolic and exemplary character. Examples where a more important number of books were destroyed are rare. As far as Christian books are concerned, one can only point to the aforementioned dramatic burning of John Wyclif's works in Prague in 1410, when more than 200 copies are said to have been destroyed. ${ }^{32}$

The only notable exceptions to this general picture are those involving Jewish books. In France, manuscripts of the Talmud were seized and publicly destroyed in large quantities in the thirteenth and fourteenth centuries. In the first of these book burnings, which were instigated by Pope Gregory IX, twenty-four wagonloads of Talmudic manuscripts from all over France were publicly burnt in Paris in 1242 by order of King Louis IX. The mass of parchment that had to be incinerated was so huge that the fire reportedly burned for two days. A further six wagonloads went up in smoke later that same year. A third public burning of Jewish books was organised in Paris in 1244; others followed in 1309 and 1320-1321. Outside Paris, similar destructions of the Talmud and other rabbinic books are attested at Corbeil (1283), Melun (1299), Toulouse (1319) and Pamiers (1320-1321). ${ }^{33}$ In Spain, at the end of the fifteenth century, Jewish books were destroyed on an even more massive scale, the pinnacle being the burning of over 6000 Jewish books on the Plaza de San Estebán in Salamanca in 1490

30 Werner 2007, 80 and 133.

31 The example of Abelard is telling in this respect. In 1141, Pope Innocent II condemned Abelard as a heretic (Leclercq/ Rochais 1977, 46-48) and ordered the burning of his books wherever they might be found (Migne 1855, 517). According to Geoffrey of Auxerre, the biographer of Bernard of Clairvaux, the pope even organised a ceremonial bonfire in St Peter's (Migne 1862, 595-596: "cujus libellos piae memoriae dominus Innocentius papa secundus in urbe Roma et in ecclesia beati Petri incendio celebri concremavit"). In reality, though, perhaps only one or two books were ritually burnt on this occasion. Moreover, some members of the papal curia, such as Cardinal Guido de Castello, who became pope in 1143 as Celestine II, secretly kept their own copies of Abelard's works. Among the 56 books Celestine II bequeathed to the cathedral of his hometown were two works by Abelard; see Häring 1975, 344 (note 19) and 363-364; Mews 2002, 365-366; Declercq 2013, 134-135.

32 Werner 2007, 80 and 333. In the literature, reference is often made to the collection and subsequent burning of all Arian writings in Toledo in 587 after the Visigothic church adopted the Catholic faith; see Fargo Brown 1923, 254 and Herrin 2009, 213. The historicity of this event is, however, doubtful, see Werner 1995, 157 (note); Werner 2007, 39-40 (note) and 553.

33 Dahan 1999; Le Goff 1996, 804-807; Werner 1995, 157-162, 176 and 178; Werner 2007, 80, 122-124 and 561-568; Declercq 2013, 132-133. 
by the notorious inquisitor Torquemada..$^{34}$ These epic burnings, which in both cases express an antisemitic attitude, can be explained by the fact that the Jews were an isolated minority that could be easily targeted..$^{35}$

In principle the destruction of a heretical or unorthodox book was aimed at eradicating it from memory. The sentence passed in 1310 against Marguerite Porete, the aforementioned Beguine from Valenciennes, even uses the word 'exterminari' ${ }^{36}$ Paradoxically, however, not all the copies that were available were also actually destroyed, and this was apparently a deliberate decision taken by those who condemned these writings. When the books of Jan Hus were condemned at the Council of Constance in 1415, the commission of the faith decided to preserve his autographs. In 1435 the writings of Agostino Favaroni were burnt at the Council of Basel, but one copy of each of his three condemned treatises was preserved. These were examined again after his appeal in 1436 and finally sent to the papal palace in Avignon, where condemned books were usually deposed ("ubi libri dampnati reponi consueverunt"). ${ }^{37}$ This shows that, at least in the late Middle Ages, a copy of heretical books was officially kept in the papal library. An early-fifteenth-century catalogue of the papal library in Avignon does indeed contain a section on heretical and Jewish books ("Libri heresum et judeorum"), which includes, among others, a book by John Wyclif and several works by Peter John Olivi. ${ }^{38}$

It is not impossible that this practice is in fact much older. In 745, a synod at Rome presided over by Pope Zacharias condemned the writings of a certain Aldebert, a self-proclaimed saint who was active as bishop and missionary in Germany. The members of the synod declared that these texts-a hagiographical autobiography, a letter purportedly by Jesus that had allegedly fallen from heaven, and a prayer invoking angels with rather diabolic names-should be burnt. Pope Zacharias, however, even though he conceded that they deserved to be destroyed by fire, nonetheless decided that it was better to preserve them in the papal archives to show that they had been confuted and as proof of their author's perpetual condemnation. ${ }^{39}$

In the late Middle Ages, proscribed books were not only kept, but also studied in order to counter and refute heretical theories more effectively. This explains why universities or university professors had copies of such books, as is attested at Paris ${ }^{40}$ and Cracow. ${ }^{41}$ Moreover, in fifteenth-century Poland confiscated books were not nec-

34 Werner 2007, 80, 124 and 592-593.

35 Declercq 2013, 132 and 136.

36 Verdeyen 1985, 82.

37 See the following note.

38 Werner 2007, 346-347; Werner 1995, 169-171.

39 Tangl 1916, 117-118 and 123-124; cf. Werner 1995, 167-169 and Werner 2007, 347-349.

40 Saenger 1982, 400.

41 Kras 2014, 207. 
essarily destroyed, and were often even donated to churches. ${ }^{42}$ In the last centuries of the Middle Ages, the Church not only preserved copies of books that had been publicly burnt but also extensively documented their condemnation: lists of errors and often detailed sentences were drafted, and in some cases public notaries even drew up a written account of the solemn burning of the condemned book. ${ }^{43}$

Although books can be physically destroyed in a variety of ways-at a synod in Vercelli in 1050, for instance, a Carolingian theological work was torn to pieces ${ }^{44}-$ burning is the most effective way of destroying a text. ${ }^{45}$ Moreover, because of its strong visual component the public burning of even a single book was a potent act of communication and a ritual with a high symbolic value. Its aim was not only to silence its author and prevent the dissemination of his ideas, as was explicitly stated in the case of Abelard in the middle of the twelfth century, ${ }^{46}$ but also to set an example and warn other authors (or potential authors)-this is also expressly mentioned in the case of Abelard..$^{47}$ In the literature on the subject, the destruction of a book by fire is often explained by the purifying force that is ascribed to fire. More particularly in Antiquity, book burning was in essence a ritual of purification. ${ }^{48}$ The question is, however, whether this explanation also holds true for the Middle Ages. ${ }^{49}$ In Christianity, fire certainly had a symbolic value as it was associated with eternal damnation. Moreover, the practice of burning books was sanctioned by the New Testament (Acts 19,19). ${ }^{50}$ In my opinion, the medieval practice should therefore rather be connected with an ordeal or trial by fire. ${ }^{51}$ Bernard of Clairvaux, Abelard's fierce adversary, uses the expression 'igne examinatus' to describe the burning of one of Abelard's books at

42 Kras 2014, 223.

43 Werner 1995, 171-172 and 180-181; Werner 2007, 49-50 and 344.

44 The book in question was attributed to John Eriugena, but was in fact by another Carolingian author, Ratramnus of Corbie; see Werner 2007, 81-82.

45 Although burning books is not as simple as it may seem; see Menze/Akalin 2013/2014, 2 and 16-18. 46 When Pope Innocent II condemned Abelard as a heretic in 1141, he imposed a perpetual silence upon him (Leclercq/ Rochais 1977, 48: “eique tamquam haeretico perpetuum silentium imposuimus”), and ordered his imprisonment and the burning of his writings (Migne 1855, 517). According to Geoffrey of Auxerre, the biographer of Bernard of Clairvaux, Abelard's writings were condemned to the fire and their author to silence (Migne 1862, 312: "scripta incendio, scriptorem silentio condemnavit”); cf. Werner 2007, 74-75.

47 In his Historia calamitatum, Abelard tells how in 1121, during the Synod of Soissons, his adversaries urged the papal legate to condemn his book De unitate et trinitate divina without examination and to burn it publicly as warning to others: "Dicebant enim [...] hoc perutile futurum fidei christiane, si exemplo mei multorum similis presumptio preveniretur” (Monfrin 1959, 87).

48 Herrin 2009; Sarefield 2006; Sarefield 2007; Menze/Akalin 2013/2014, 7-8.

49 Cf. Werner 1995, 171.

50 Cf. Werner 2007, 225-227.

51 The idea of fire as a tool of God is also attested in the Christian East in late Antiquity; see Menze/Akalin 2013/2014, 14-15. 
Soissons in $1121 .^{52}$ This expression means 'judged' or 'examined by fire', and the term is also used in the Middle Ages in connection with a trial by fire. ${ }^{53}$

This helps to explain why in several legendary stories books are subjected to this ordeal. The best known story, told by Jordan of Saxony in the 1230s and perpetuated in a painting by Pedro Berruguete in the late fifteenth century, tells how a book of the Cathars and a book by St Dominic were subjected to a trial by fire at Fanjeaux in 1207: the Cathar book was destroyed by the flames, while the Catholic book jumped out of the fire, even when it was thrown back twice. ${ }^{54} \mathrm{~A}$ similar story can be found in Spain in connection with the introduction of the Roman liturgy in the late eleventh century. According to a colourful story in the chronicle of the monastery of Nájera, King Alfonso VI of Castile and León intervened during a trial by fire in 1077 by kicking the Mozarabic book that leapt from the fire back into the flames. ${ }^{55}$ Similarly, an early medieval Irish hagiographical source, the Life of St Fintan (or Munnu), reports a discussion at a synod held in 631 between the supporters of the old (Irish) method of calculating Easter and the new (Roman) method. During this debate, Fintan, who defended the old computus, is said to have proposed throwing two books, the old and the new, into the fire to see which of them would survive the ordeal. ${ }^{56}$

The message from these rather far-fetched stories seems to be that fire was seen as a tool of God and that the burning of books was therefore the will of God. Those who acted as guardians and defenders of orthodoxy, like Bernard of Clairvaux, do not refer to such legends but they knew their classics, i. e. the Bible and the history of the Church. From the latter they learnt that ever since the days of Emperor Constantine, who ordered the burning of the works of Arius after his condemnation at the Council of Nicaea, countering heresies had always been envisaged in terms of burning books. ${ }^{57}$ They also knew the statement by St Paul in his first letter to the Corinthians that heresies were needed (1 Cor 11,19: “oportet et haereses esse”), because

52 Leclercq/Rochais 1977, 41-42 (letter to Pope Innocent II, written by Bernard in the name of the archbishop of Reims and the bishops of Soissons, Châlons and Arras): "Iamdudum fecerat librum de sua Trinitate, sed sub legato Romanae ecclesiae igne examinatus est, quia inventa est in eo iniquitas"; Bernard of Clairvaux refers to the Synod of Soissons in 1121, where Abelard was forced to cast his own book into the fire; see Werner 2007, 131-134 and 558; Declercq 2013, 134.

53 Cf. Werner 2007, 99.

54 Cuperus 1733, 547-548; on the development of this legend, cf. Werner 2007, 204-218 and 653-654. 55 Walker 1998, 31. Another source, from the abbey of San Millán de la Cogolla, suggests that during the introduction of the Roman liturgy Mozarabic missals were burnt (ibidem, 33 and 226).

56 Stevens 1981, 84 and 103 note 4.

57 In a series of letters, addressed mainly to Roman officials (Pope Innocent II and several cardinals), Bernard of Clairvaux compares Abelard to three well-known heretics from late Antiquity: Arius, Pelagius and Nestorius (Leclercq/Rochais 1977, 44, 268, 270, 272, 276, 278). When Pope Innocent II condemned Abelard in 1141, he referred explicitly to the condemnation of Arius at the Council of Nicaea and the condemnation of Nestorius at the Councils of Ephesus and Chalcedon (ibidem, 47). 
these allowed a better definition and circumscription of orthodoxy..$^{58}$ Seen from this perspective, each and every public burning of heretical or unorthodox books was a public reaffirmation of orthodox doctrine. It was, in other words, an act of faith, an 'actus fidei' in the strict sense of the word.

Apart from the public destruction of books, which was largely symbolic as we have seen, texts could of course also be destroyed quietly and without fanfare. This could even happen in the case of condemned books. In 1255, Pope Alexander IV ordered the bishop of Paris to destroy the so-called Introduction to the Eternal Gospel, a millenarian work by a Franciscan author, Gerard of Borgo San Donnino, but he made a point of asking the bishop to carry out this destruction discreetly, so as not to harm the Franciscan order. ${ }^{59}$ A few years later, in 1258, the Franciscan chronicler Salimbene de Adam found in the convent of his order at Imola a copy of this book, which was burnt immediately on his advice. ${ }^{60}$ The case of Gerard's book, which circulated widely within the order as well as outside, ultimately led to the imposition of preventive censorship in the Franciscan order in 1260. Henceforth, no member of the order could publish a book outside the order without the permission of his superiors. ${ }^{61}$ This censorship was imposed at the general chapter of the order at Narbonne presided over by its minister-general Bonaventure. At the next chapter, in 1266, an even more far-reaching decision was taken: the so-called Legenda maior composed by the same Bonaventure was accepted as the official life of St Francis, and all other 'legendae' circulating within the order were to be destroyed. The order's members were even urged to fetch back copies that were preserved outside the order. This is a telling example of the canonisation of a particular text and an attempt to eliminate all alternative biographies. Part of a vain endeavour to restore the order's unity, it took place against the background of a growing rift within the Franciscan order between the so-called Conventuals (the moderate pragmatic wing) and the Spirituals (a more radical, dissident minority), regarding the legacy of its founder. ${ }^{62}$

Even though parchment was an expensive material in the Middle Ages, recycling it in the form of palimpsests was never really an option in the case of condemned

58 The passage is quoted by Bernard of Clairvaux in two letters against Abelard: Leclercq/Rochais 1977, 15 (to Pope Innocent II) and 275 (to an abbot). On this biblical passage, cf. Werner 1995, 174. Ironically, it was also used by Jan Hus in his tract De libris hereticorum legendis, written hastily in 1410 in a vain attempt to prevent the burning of Wyclif's books in Prague; in this rather provocative text, Hus stressed that Christians should "read the books of heretics and not burn them"; according to him "one is permitted to read and to have in one's home the books of authors, some containing, in spite of certain false or heretical opinions, much truth useful to the church" (Fudge 2016, 147-149, at 147 and 148); see also Werner 2007, 371-373.

59 Denifle/Châtelain 1889, 297-298.

60 Scalia 1999, 691.

61 Bianchi 1999, 29-32. The link between this measure and Gerard of Borgo San Donnino's book is explicitly attested by Salimbene de Adam: Scalia 1999, 698.

62 See Le Goff 1999, 40-48; cf. Werner 1995, 154-155. 
texts. ${ }^{63}$ As we have seen, they had to be burnt publicly and solemnly. In other words, it was not the destruction of the text as such that mattered, but the public nature of the event and the message that it mediated. It was, however, once thought that Christians in the early Middle Ages had tried to destroy pagan literature by palimpsesting ancient manuscripts. Pope Gregory the Great in particular was accused, from the twelfth century onwards, of having ordered the destruction of entire libraries. ${ }^{64}$ Scholars of the nineteenth and early twentieth century therefore assumed that the early medieval palimpsests in which works of authors such as Cicero, Livy, Plautus, Lucan and Sallust lay buried under Christian texts were the result of a deliberate effort by monks to destroy classical literature. This view has long since been abandoned. In fact, the Latin classics were sacrificed because they had become obsolete: there was a general lack of interest in classical literature during the seventh and early eighth centuries, and parchment was too precious to carry texts that were no longer read. ${ }^{65}$ Even the Arian texts, especially the translations of the Bible in the Gothic language, were probably not palimpsested because of their content, although there may be exceptions. An intriguing palimpsest fragment from the abbey of Bobbio, today preserved in Milan, contains as upper text the Latin version of the last chapter of the Gospel of Matthew, and as lower text the Gothic version of the same chapter. ${ }^{66}$ In this particular case it may indeed not be impossible that the Gothic-and hence heretical-version of the Gospels has been deliberately erased and replaced with the Latin-and therefore Catholic-version. The fact that texts could indeed be palimpsested because of their content is effectively attested in the middle of the thirteenth century by a passage in the chronicle of the Franciscan Salimbene de Adam, who tells us that in the Cistercian monastery of Fontana Viva near Parma the prophetic texts of an author from Verona had been palimpsested because of the enormous scandal that these prophecies had provoked. ${ }^{67}$

\section{The Destruction of Documents}

Throughout the Middle Ages not only books but also archival documents were deliberately destroyed on account of their content. The reasons and circumstances of these destructions differ greatly, but we can roughly distinguish two possibilities: on the one hand, the premeditated destruction-publicly or secretly-of one or more specific documents by an authority, an institution, a group of persons (e. g. rebels) or a single

63 With regard to late Antiquity, cf. Menze/Akalin 2013/2014, 8.

64 Werner 2007, 27.

65 Beeson 1946; Lowe 1972, 483; Declercq 2007, $13-14$.

66 Beeson 1946, 166.

67 Scalia 1999, 689-691. 
private person; on the other, the more or less spontaneous and often violent destruction of a large number of documents during an act of collective anger. ${ }^{68}$ Examples of both can already be found in the late sixth century in the work of Gregory of Tours. He relates, for instance, how the Frankish kings Clothar I and Charibert granted and confirmed to the town of Tours an immunity from taxation by throwing the tax-lists into the fire. In another passage, Gregory describes how the people of Limoges seized the fiscal lists and burnt them to ashes when King Chilperic I decreed the levy of a new series of taxes. ${ }^{69}$ As the first example shows, the destruction of documents ordered by the authorities could be an act of munificence. ${ }^{70}$ More often than not, though, it was a punitive measure that belonged to the repertoire of repression at the disposal of kings, princes and lords.

Violent destructions of documents often happened in periods of political upheaval and rebellion. During revolts, whole archives were sometimes destroyed because they were seen as symbolising the existing order. ${ }^{71}$ Examples of such collective destructions are particularly numerous during the late Middle Ages. In the fourteenth century, peasants, sometimes associated with unskilled labourers, raided communal archives in several Italian towns (Modena 1305, Parma 1308, Novara 1356), ripping to shreds, burning or tossing down a well not only judicial registers and tax surveys but also ancient charters and notarial books, with the aim of freeing themselves of fines and taxes. ${ }^{72}$ In Italian towns, archives were also targeted during internal conflicts in order to destroy the documents on which the rights of the adversary were based..$^{73}$ But the most spectacular destructions of this kind occurred in England in 1381, during the Peasant's Revolt. ${ }^{74}$ The burning of charters, court rolls and other documents has even been described as 'the most universal feature' of the Revolt. No fewer than 107 separate instances of the destruction of documents have been identified. In some cases, as in the archbishopric of Canterbury or Waltham Abbey, entire estate archives were destroyed by fire. ${ }^{75}$ A contemporary chronicler, Thomas Walsingham, states that the rebels "made it their business to burn ancient muniments; and so that no one could be found again who had the ability or the knowledge to later commit to memory

68 Cf. Adamska/Mostert 2006.

69 Krusch/Levison 1951, 448-449 (Tours) and 233-234 (Limoges).

70 See also Sennis 2013, 156. For a twelfth-century example, cf. Declercq 2013, 154-155.

71 Cf. Mauntel 2015, 107: "During revolts, written documents were broadly considered to be material manifestations of the existing order or of the law itself. [...] The actual legal content was transcended and the document became a representation of what the protest was directed against”.

72 Cohn 2006, 12 and 44.

73 Koch 1995, 65. Cf. Weber 2014, 264: “The practice of written administration and archiving by the commune, its institution of archives to the end of control and repression, and their keeping in the commune's central buildings had as a consequence that during political and social conflicts violence was also addressed against the archives”.

74 Crane 1992; Justice 1994; Mauntel 2015.

75 Crane 1992, 204. 
things old or new, they murdered men of that sort"; according to Walsingham "it was dangerous to be recognised as a clerk, but much more dangerous if an inkpot were found by anyone's side, for such men never, or scarcely ever, escaped from their [i. e. the rebels'] hands". ${ }^{76}$ In Cambridge, where charters and university books were burnt in one large bonfire in the market square, an old woman named Margaret Starre scattered the ashes to the wind, crying: "Away with the knowledge of clerks, away with it". ${ }^{77}$ To the English rebels of 1381, writing was clearly an instrument of oppression that had to be destroyed, but at the same time they wanted to obtain for themselves charters of manumission from the king. This is not a contradiction or a paradox. Steven Justice, author of a book on 'Writing and Rebellion' in England in 1381, has shown that the rebels, although illiterate in the strict sense of the word, had nonetheless a sense of practical literacy. They were familiar with written documents and, more particularly, they understood that if writing could be used to oppress them it also had the potential to liberate them. ${ }^{78}$ As the systematic destruction of documents is a common feature of revolts, not only in England in 1381, but also in Germany in 1525 and in France in 1789, Peter Burke has suggested that such destruction "may be interpreted as the expression of the belief that the records had falsified the situation" and that "they were biased in favour of the ruling class, while ordinary people remembered what had really happened". ${ }^{79}$ Or, as Steven Justice put it: "The rebels aimed not to destroy the documentary culture of feudal tenure and royal government, but to re-create it". 80

Archival documents, especially charters, could also be destroyed publicly during a solemn ceremony staged by the authorities as well as by rebels. Unlike books, the public burning of documents was rather rare, at least in the late Middle Ages. The famous letter Ausculta fili addressed by Pope Boniface VIII to Philip the Fair of France in 1302 was burnt on the king's orders, but that may have been because Philip and his entourage accused the pope of heresy. ${ }^{81}$ In Braunschweig, the privileges of the craft-guilds were publicly destroyed in 1490 after a revolt: first the seals were cut off, then the charters were burned. ${ }^{82}$ Forged charters, once they were identified as such, could also be burnt. ${ }^{83}$ Normally, though, documents were either torn to pieces, cut up or symbolically cancelled. ${ }^{84}$ In 1175 , a dispute over the church of Langrickenbach in

76 Taylor/Childs/Watkiss 2003, 497; Crane 1992, 204. On this often quoted passage, cf. also Justice 1994, 18 and 198; Mauntel 2015, 103-104.

77 Crane 1992, 215 and 221 (note 51); cf. Justice 1994, 72.

78 Justice 1994.

79 Burke 1997, 56.

80 Justice 1994, 48.

81 Werner 2007, 88.

82 Mersiowsky 2010, 31.

83 See Foerster 1955, 309; Declercq 2013, 160.

84 In fact, several methods could be combined. In 1151, Geoffrey V Plantagenet, Count of Anjou, came to the monastery of St Aubin in Angers, where he destroyed a chirograph, once sealed by himself, in 
Thurgau (Switzerland) ended with the destruction of a false charter during a solemn session in Constance Cathedral: the seal was broken into small pieces, the parchment was cut up and the snippets dispersed in front of the audience. ${ }^{85} \mathrm{~A}$ papal letter from Benedict XIII to the French king Charles VI was solemnly condemned and destroyed during a ceremony in the gardens of the royal palace in Paris in May 1408: the parchment was first cut up and then torn to pieces by the rector of the University. ${ }^{86}$

The public destruction of important documents sent such a potent message that rebels often organised similar spectacles too. During the revolt in Bruges following the death of Charles the Bold, Duke of Burgundy, in 1477, the so-called 'Peace of Arras', a hated charter imposed upon the town by Charles's father Philip the Good in 1438 was publicly and solemnly torn to pieces together with three other charters in a ceremony in front of the town hall. Before their destruction these documents, which had been retrieved from the archives of the County of Flanders in Lille, were shown to the public, read out in French and translated into Dutch. To emphasise the solemnity of the event, the man who 'executed' the documents, the Lord of Gruuthuse, wore the insignia of the Order of the Golden Fleece and the platform on which he was standing was decorated with cloth of gold. ${ }^{87}$ Several decades earlier, in 1411, the craft-guilds of Bruges had forced the Burgundian duke John the Fearless to hand over to them another hated charter, the so-called Calfvel, or 'Calfskin'-a name expressing their contempt for this charter, which John had imposed upon them in 1407. In this case, the deans of the craft-guilds first broke the seals, then tore the charter apart with their teeth, "into a thousand pieces", according to a chronicler. ${ }^{88}$ Even the English peasant rebels of 1381 sometimes chose a public place (e.g. the market square) to burn the documents they wanted to destroy. As Christoph Mauntel has stressed, "the visibility of the act had a symbolic value in itself", for in this way "the documents' destruction became a collectively and solemnly celebrated ceremony of liberation". 89

In all the examples cited thus far the documents were physically destroyed, either by burning or being torn to pieces. From the late tenth century and possibly even earlier, however, another, less destructive method might be used, by which a charter was 'cancelled'. This was a ritual invalidation during which one or more cuts were

the presence of the abbot and the monks: he cut the parchment into small pieces and cast them into the fire; see Declercq 2013, 154-155. For another example, cf. Sennis 2013, 155.

85 According to the charter of the bishop-elect of Constance, his intention was initially to burn the charter; see Meyer 1917, 189-196; Mente 2004, 437-438; Foerster 1955, 311-312.

86 Werner 2007, 88-89.

87 Van Leeuwen 2008, 310 and 313. This study gives no details about the way the charters were destroyed, but one of the two sources referred to by Van Leeuwen (the Excellente cronike van Vlaenderen, published in 1531) says that the charter of 1438 was torn up: "Doe bleef te Brugghe tcalfsvel geschuert" (fol.180r).

88 De Jonghe 1837-1840, vol.3, 227; Fris 1911, 260-262; Dumolyn 1997, 139-140; Van Leeuwen 2008, 310 and 314.

89 Mauntel 2015, 100. 
made in the parchment with a knife or scissors. These incisions automatically invalidated the charters in question. ${ }^{90}$ Many charters that were cancelled in this way during the late Middle Ages or even in the sixteenth century are still preserved today. The origin of the practice is not clear. In my opinion there is no link with the 'transpunctio cartae' or piercing of a charter known from the early Middle Ages, ${ }^{91}$ for this ritual was used to contest a charter in court but did not invalidate it. ${ }^{92}$ The ritual cancellation was already known in tenth-century Italy, even though there is some uncertainty about the first example. In 968, during a court session in the Italian town of Fermo, Hubert, arch-chancellor of Otto the Great, invalidated a charter of Emperor Berengar for the diocese of Fermo that contradicted an earlier charter of Charles the Fat for the abbey of Santa Croce sul Chienti by breaking the seal and cutting up the parchment. The terminology used in the charter that describes the event-scissaque membranais, however, somewhat ambivalent, for it is not clear whether the arch-chancellor merely made a few incisions or cut the parchment into several pieces. ${ }^{93}$

To my knowledge, the first certain example of this ritual therefore occurs some decades later during a court session in Rome in 998. In the course of a dispute between Farfa Abbey and the clerics of the church of St Eustachius in Rome, a charter produced by the Roman clerics was publicly destroyed by making a cross-shaped cut in the parchment ("signum sanctę crucis in ea abscidendo per medium fecit"). ${ }^{94}$ In the same case, two more charters produced by the clerics of St Eustachius were legally invalidated in the same way in 1011 ("eas per medium abscidit similitudine crucis"). ${ }^{95}$ Both in 998 and in 1011, the invalidated documents were handed over to the abbot of Farfa. Later, though, charters that were ritually cancelled were usually confiscated and thenceforth kept in royal or princely archives. The first example of this practice also comes from Italy. In 1148, a charter of Roger II of Sicily for the diocese of Patti mentions an invalidated charter of the bishop of Messina from 1104 that is preserved in the royal archives ("cassatum, infirmatum et ruptum in regiis scriniis detinetur"). ${ }^{96}$

Ritual cancellation could happen in a judicial context, when a charter contradicted another charter, ${ }^{97}$ or when a charter was declared to be false. ${ }^{98}$ In the late

90 The principle that a charter should be "non cancellatum, neque abolitum, neque ex quacumque suae formae parte viciatum” is enshrined in Roman Law (Codex Justiniani 6, 33, 1).

91 Adamska/Mostert 2006, 702 suppose such a link.

92 See Declercq 2013, 159-160.

93 Sickel 1879-1884, 504. On another occasion, probably in 962-965, a charter of the Italian king Lothar that was detrimental to the abbey of Novalesa was burnt on the orders of Otto I "coram cunctis principibus suis, videlicet marchionibus, episcopis, commitibus et abbates" (Bethmann 1846, 115 and 123). For both cases, cf. also Sennis 2004, 110; Sennis 2013, 158.

94 Sickel 1888-1893, 703.

95 Giorgi/Balzani 1888, 14; Sennis 2004, 111; Sennis 2013, 159.

96 Brühl 1978, 55, 159 and plate XIII.

97 See the case of 968 mentioned in note 93.

98 Manaresi 1958, 512-513 (Verona, 1013: “ipsa cartula [...] reproba et falsidica inventa fuit [...] ipsi 
Middle Ages, it was also used as a political instrument, more particularly as a punitive measure against rebellious towns. In late-medieval Flanders urban privileges were frequently confiscated and invalidated in this way. The dukes of Burgundy in particular seem to have preferred this kind of symbolic destruction to the physical destruction of the charters. It allowed them to stage a dramatic spectacle, which demonstrated their princely power and humiliated the insurgents. The most spectacular examples concern the town of Ghent. To punish the town for the riots that had disturbed his solemn entry into the town in 1467, Charles the Bold forced its citizens to hand over to him an important privilege issued by Philip the Fair of France in 1301. During an impressive ceremony in the great hall of the palace in Brussels in January 1469, the charter was solemnly invalidated in the presence of the entire court and seventeen foreign ambassadors. For the representatives of the town of Ghent, the ceremony started with a threefold humiliation: the aldermen of the town and fifty-two of its guild deans were made to wait for over an hour and a half in the snow outside the hall; when they were finally allowed to enter they had to prostrate themselves three times and lay down the banners of the guilds, crying "mercy" in unison. After that, a representative of the town, Boudin Goethals, handed over the royal charter to the duke, who was seated on an elevated throne. The chancellor of Burgundy, Pierre de Goux, first read the text of the privilege, then, on the duke's order, another high official, Jean Gros, first secretary and 'audiencier', cancelled it with a knife. ${ }^{99}$ The original of this charter is still preserved. It has three angled or hook-shaped incisions in the middle. The form of these incisions shows that the charter was folded before being cut three times in the central fold. ${ }^{100}$ Furthermore, on the back, just below the incisions, Jean Gros, the man who cancelled it, wrote a note that actually gives a short account of the ceremony. ${ }^{101}$ In 1485, Archduke Maximilian of Austria ordered the similar cancellation of nine of Ghent's more recent privileges in a ceremony held in the great hall

sacramenti facti, predicta cartula incisa fuit”) and 581 (Treviso, 1017: "ipsa cartula [...] reproba et falsidica inventa fuit et ibi incisa”); for the Verona case, cf. Sennis 2004, 109-110; Sennis 2013, 158. For a French example from 1331, see Declercq 2013, 160.

99 Gachard 1833, 204-209; Arnade 1991, 91-92; Boone 2003a, 24-27.

100 This was the usual way in which the Burgundian chancery cancelled charters; see Nelis 1927, 772 and plate I, "figure" I.

101 Boone 2003a, 40 (photo of the cancelled charter) and 41-42 (edition of the note on the back); see also Mauntel et al. 2015, 743. It should be noted that the seal of this charter is still intact, apparently because Charles the Bold and his officials did not dare to break this royal symbol. The confiscated charter (today: Paris, Bibliothèque Nationale de France, Mélanges Colbert, no. 347, charter no. 59) was sent to the archives of the 'Chambre des Comptes' in Lille, where it was registered in an inventory from 1471 and copied (with the note on the back) in the 'registre des chartes' for the years 1469-1475 (Boone 2003a, 26-27). A second original, also cancelled (but here the seal has disappeared) is preserved at the Municipal Archives in Ghent. As the technique used to cancel this original is different (it has a long rectilinear and diagonal incision), it was probably cancelled only in 1540, when Emperor Charles V confiscated all the privileges of the town; see Declercq 2013, 158 (note 135). 
of the princely residence there. ${ }^{102}$ The lesson was not lost on the citizens of Ghent, who quickly saw the impact that such a ritual destruction of documents could make. Following Charles the Bold's death in 1477 they subjected three charters that he and his father Philip the Good had imposed upon the town (the Peace of Gavere of 1453, a related charter and the so-called 'restriction de Gand' of 1468) to the same treatment. During a plenary session of Ghent's great council in February 1477 the hated charters were solemnly cancelled. ${ }^{103}$ Carefully staged events like these show that the ritual destruction of a charter was an act of symbolic communication as potent as the physical destruction of the parchment.

Both the physical and ritual destruction of important documents in a public ceremony were indeed impressive acts of symbolic communication. Often performed in the context of a revolt or its repression, such destruction expressed political supremacy and triumph and at the same time showed that the juridical situation embodied in the documents was abolished. ${ }^{104}$ To annul a charter, it was not enough to declare that it was null and void. The material object had to be displayed and invalidated through an act of physical or symbolic destruction, so that everyone could see that it was no longer valid. The publicity of the event was therefore an essential feature, not least because the destruction or invalidation of a charter was a legal act. ${ }^{105}$ Medieval charters were public documents. They were issued in the presence of witnesses during a public performance in which speech, writing and ritual played a role. Royal privileges and other important documents in particular were often displayed in public ceremonies, where they were shown and read aloud. Destroying important charters in public can thus be considered "an inversion of the public presentation and display of the records at the time they were issued", as Christoph Mauntel has stated. ${ }^{106}$ When a charter was issued it was first written, then sealed, and finally read aloud. During a ritual of destruction the order was reversed: it was first read aloud, then the seal was broken and finally the parchment was cut up or torn to pieces. ${ }^{107}$ Just like the promulgation of a charter, its official destruction also had a strong ritual dimension. ${ }^{108}$ More particularly, it is striking that several accounts of legal destruction explicitly mention the fact that the 'executioner' took a knife (998: "iussu domni Leonis tulit Leo arcarius sanctę apostolicę sedis cultrum”; 1011: "iussu domni patricii et praefecti et cunctorum iudicum, tulit Gregorius primicerius defensorum cultellum”; 1469: "mons ${ }^{\mathrm{r}}$ maistre Jehan le Groz, premier secretaire et audiencier, prinst ung canyvet ou tailgeplume”),

102 Doutrepont/Jodogne 1935, 467-468; Gachard 1852, 8-9 and 95-96; Van Leeuwen 2008, 315-316.

103 Fris 1904, 250; see Van Leeuwen 2008, 314; Boone 2003b, 52.

104 Cf. Van Leeuwen 2008, 316 and 322.

105 Cf. Sennis 2013, 163: "destroying a document was-it had to be-a public act and, as such, it gained all its strength from the fact that it was manifest".

106 Mauntel 2015, 99-100.

107 Cf. Worm 2008, 69.

108 Cf. Sennis 2013, 158. 
thus indicating that this dramatic gesture was a key element in the public performance. ${ }^{109}$

Exceptionally, a charter that normally should have been destroyed publicly could also be disposed of in a more discreet manner. In 1114 the archbishop of Auch ordered the canons of Oléron Cathedral to burn a forged charter fabricated by their recently deceased bishop, but to do so secretly-'in occulto'-so as not to harm the memory of the prelate. ${ }^{110}$ As charters were title deeds, they could of course also be targeted by people with inimical intentions and destroyed maliciously without anyone witnessing the deed. Numerous examples could be cited from the early Middle Ages onwards of charters that were stolen or burnt or that simply disappeared. Generally, this was the work of private individuals, but lords or bishops could also be implicated, as well known cases from the eighth and ninth centuries involving the abbeys of St Victor in Marseille and St Gall show. ${ }^{111}$ In the case of sealed charters it was not even necessary to steal or destroy the charter. Breaking or pulling off the seal was sufficient to invalidate the document. ${ }^{112}$ Normally, these acts were directed against original charters, but there were some who were keen to ensure that no copies existed and if they did, took pains to see that they disappeared too. In the early ninth century, the bishop of Constance managed to lay hands on an important royal charter for the abbey of St Gall that he wanted to destroy. He forced a monk, who was said to have intended to copy the charter, to swear on the relics of St Gall that he had not done so. Reassured by this oath, the bishop returned home to Constance and flung the royal charter into the fire. ${ }^{113}$ In the mid-twelfth century a knight from Cluny sought to recover a property that his parents had donated to Macon Cathedral. Two of his cousins, who were canons of the chapter, simply took the cathedral's cartulary or copy-book and removed and destroyed the page that his parents' charter was copied on. ${ }^{114}$ Copies of documents could also be deleted officially after their originals had been publicly destroyed or cancelled. This happened in Ghent during the revolt of February 1477: the cartulary copies of the hated charters from 1453 and 1468 were crossed out. ${ }^{115}$

109 Sickel 1888-1893, 703; Giorgi/Balzani 1888, 14; Gachard 1833, 208.

110 Foerster 1955, 309-310.

111 Declercq 2013, 153-154.

112 Declercq 2013, 154; Adamska/ Mostert 2006, 703-704.

113 Declercq 2013, 154.

114 Ragut 1864, 372.

115 Gachard 1852, 56-57. 


\section{Conclusion}

After this brief survey of the deliberate destruction of texts in the Middle Ages, it will be clear that the public and solemn character of the event was an important feature of the destruction of both books and documents. Staging the destruction of writing in a dramatic way is a potent form of symbolic communication. We have seen that the destruction of books and charters was organised as a spectacle, particularly in the last centuries of the Middle Ages. It was a public performance, which combined verbal with non-verbal communication. In Prague, books were burnt while the deathbell tolled, ${ }^{116}$ and in late medieval France, documents were torn to pieces to the sound of trumpets. ${ }^{117}$ As Asa Briggs and Peter Burke have stated, "what needed to be remembered had to be presented in a memorable way". They also stress that "ritual with its strong visual component was a major form of publicity", 118 and that "the most effective forms of communication" were "those which appealed simultaneously to the eye and to the ear". ${ }^{119}$ There can be little or no doubt that the burning of books and the real or symbolic destruction of important charters during an elaborate and solemn ceremony must have had a profound impact on those who witnessed it. Ritual is indeed an important medium, and in this case it was clearly organised for maximum effect. A ceremonial book burning by religious authorities, a large bonfire built by rebels to destroy manorial archives, the solemn invalidation of urban privileges by a lord or prince-in a sense these spectacles all illustrate McLuhan's memorable oneliner, "the medium is the message". In fact, as David Cressy has argued with regard to book burning in sixteenth-century England, the public destruction of books and documents was both medium and message. Each and every ceremonial burning of heretical or unorthodox writings was not only a disavowal of a particular heretical or heterodox text, but also a re-affirmation of orthodoxy. The solemn destruction or invalidation of charters, on the other hand, was often meant to express triumph over political adversaries.

Above all, perhaps, destroying texts in a public setting was a way of demonstrating authority and displaying power. ${ }^{120}$ Daniel Sarefield argues that "as ritual and spectacle" a book burning "served as an 'idiom of authority' for those who deployed it". ${ }^{121}$ The same is true of the public destruction of documents, at least when it was performed in a political context. Destroying writing belonged to the repertoire of communications at the disposal of those who were in power. In the words of David Cressy,

116 Cf. note 24.

117 Werner 2007, 93 and 96 (note).

118 Briggs/Burke 2009, 8-9.

119 Briggs/Burke 2009, 34.

120 Cf. Cressy 2005, 361 and 374.

121 Sarefield 2007, 159. 
it was "didactic, polemical, punitive, and instructive". ${ }^{122}$ That the intended audience understood this, can be deduced from the fact that rebels, whenever they were in a position to do so, imitated the practices of the authorities in this regard. Christoph Mauntel is right, therefore, when he concludes that "large parts of society spoke and understood the same 'language of action', strongly relying on visibility, symbolism and materiality". ${ }^{123}$ It is precisely the materiality of texts-and hence their performative potential-which makes it possible to use their destruction to convey a message of authority and domination.

Finally, the destruction of writing also shows the importance that was attached to the written word. Walter Ong explains the destruction of texts, and particularly the burning of books, by what he calls the "inherently contumacious" nature of writing: "There is no way directly to refute a text. After absolutely total and devastating refutation, it says exactly the same thing as before. [...] A text stating what the whole world knows is false will state falsehood forever, so long as the text exists". ${ }^{124}$ Destroying a text-be it a book or a charter-was therefore an admission of the power ascribed to writing. ${ }^{125}$ Or, to put it differently, those who destroyed texts-as Rosamond McKitterick has stated-“out of fear of their power, clearly appreciated the potency of the written word”. ${ }^{126}$

\section{Bibliography}

Adamska, Anna / Mostert, Marco (2006), “The 'Violent Death' of Medieval Charters: Some Observations on the Symbolic Uses of Documents”, in: Paweł Kras and Agnieszka Januszek (eds.), Ecclesia, cultura, potestas. Studia z dziejów kultury i spoleczenstwa, Cracow, 699-710.

Arnade, Peter J. (1991), "Secular Charisma, Sacred Power: Rites of Rebellion in the Ghent Entry of 1467", in: Handelingen der Maatschappij voor Geschiedenis en Oudheidkunde te Gent. Nieuwe Reeks 45, 69-94.

Beeson, Charles Henry (1946), "The Palimpsests of Bobbio”, in: Miscellanea Giovanni Mercati 6, Vatican City, 162-184.

Bethmann, Ludwig Conrad (ed.) (1846), “Chronicon Novaliciense”, in: Monumenta Germaniae Historica. Scriptores 7, Hannover, 73-133.

Bianchi, Luca (1999), Censure et liberté intellectuelle à l'Université de Paris (XIII'-XIVe siècles), Paris.

Boone, Marc (2003a), “Het 'Charter van Senlis' (november 1301) voor de stad Gent. Een stedelijke constitutie in het spanningsveld tussen vorst en stad”, in: Handelingen der Maatschappij voor Geschiedenis en Oudheidkunde te Gent. Nieuwe Reeks 57, 1-45.

Boone, Marc (2003b), “La justice en spectacle. La justice urbaine en Flandre et la crise du pouvoir ‘bourguignon' (1477-1488)”, in: Revue historique 308, 43-65.

122 Cressy 2005, 374 (with regard to book burning in sixteenth-century England).

123 Mauntel 2015, 108.

124 Ong 2002, 78; cf. Ong 1986, 27.

125 Cf. Herrin 2009, 206 and 211.

126 McKitterick 2004, 219. 
Briggs, Asa / Burke, Peter (32009), A Social History of the Media from Gutenberg to the Internet, Cambridge.

Brühl, Carlrichard (1978), Urkunden und Kanzlei König Rogers II. von Sizilien (Studien zu den normannisch-staufischen Herrscherurkunden Siziliens 1), Cologne/Vienna.

Burke, Peter (1997), “History as Social Memory”, in: Peter Burke, Varieties of Cultural History, Cambridge, 43-59.

Cauchie, Alfred (1914-1920), "Serrurier (Nicole)", in: Biographie nationale 22, Brussels, 273-277.

Clanchy, Michael T. (21993), From Memory to Written Record. England 1066-1307, Oxford/ Cambridge, MA.

Cohn, Samuel K. (2006), Lust for Liberty. The Politics of Social Revolt in Medieval Europe, 1200-1425, Cambridge, MA.

Crane, Susan (1992), “The Writing Lesson of 1381”, in: Barbara A. Hanawalt (ed.), Chaucer's England. Literature in Historical Context (Medieval Cultures 4), Minneapolis, 201-221.

Cressy, David (2005), "Book Burning in Tudor and Stuart England”, in: The Sixteenth Century Journal. The Journal of Early Modern Studies 36, 359-374.

Cuperus, Guilielmus (1733), “Acta S. Dominici confessoris”, in: Acta Sanctorum Augusti. Ex Latinis \& Graecis, aliarumque gentium Monumentis, servata primigenia veterum Scriptorum phrasi. Tomus I, Antwerp, 545-559.

Dahan, Gilbert (ed.) (1999), Le brûlement du Talmud à Paris (1242-1244), Paris.

Declercq, Georges (2007), “Codices Rescripti in the Early Medieval West”, in: Georges Declercq (ed.), Early Medieval Palimpsests (Bibliologia 26), Turnhout, 7-22.

Declercq, Georges (2013), "Habent sua fata libelli et acta. La destruction de textes, manuscrits et documents au Moyen Âge”, in: David Engels, Didier Martens and Alexis Wilkin (eds.), La destruction dans l'histoire. Pratiques et discours, Brussels, 129-161.

Denifle, Henri / Châtelain, Emile (eds.) (1889), Chartularium universitatis Parisiensis, vol. I, Paris. Doutrepont, Georges / Jodogne, Omer (1935), Chroniques de Jean Molinet. Tome 1, Brussels. Dumolyn, Jan (1997), De Brugse opstand van 1436-1438, Heule.

Eco, Umberto (1998), Faith in Fakes. Travels in Hyperreality, trans. William Weaver, London.

Fargo Brown, Louise (1923), “On the Burning of Books”, in: Christabel Forsyth Fiske (ed.), Vassar Mediaeval Studies, New Haven, 249-271.

Foerster, Hans (1955), “Beispiele mittelalterlicher Urkundenkritik”, in: Archivalische Zeitschrift 50/51, 301-318.

Fris, Victor (ed.) (1904), Dagboek van Gent van 1447 tot 1470 met een vervolg van 1477 tot 1515. Deel 2, Ghent.

Fris, Victor (1911), “Het Brugsche Calfvel van 1407-1411”, in: Bulletin de l'Académie royale d'Archéologie de Belgique, 183-274.

Fudge, Thomas A. (2016), Jan Hus between Time and Eternity. Reconsidering a Medieval Heretic, Lanham.

Gachard, Louis-Prosper (ed.) (1833), Collection de documens inédits concernant l'histoire de la Belgique. Tome premier, Brussels.

Gachard, Louis-Prosper (1852), Notice historique et descriptive des archives de la ville de Gand, Brussels.

Giorgi, Ignazio / Balzani, Ugo (eds.) (1888), Il regesto di Farfa di Gregorio di Catino, vol. 4, Rome.

Le Goff, Jacques (1996), Saint Louis, Paris.

Le Goff, Jacques (1999), Saint François d'Assise, Paris.

Goll, Jaroslav (ed.) (1893), “Tak zvaná Kronika university pražské”, in: Fontes rerum Bohemicarum 5 , Prague, 565-588.

Häring, Nikolaus M. (1975), “Abelard Yesterday and Today”, in: René Louis, Jean Jolivet and Jacques Châtillon (eds.), Pierre Abélard. Pierre le Vénérable. Les courants philosophiques, littéraires et artistiques en Occident au milieu du XII e siècle, Paris, 341-403. 
Herrin, Judith (2009), “Book Burning as Purification”, in: Philip Rousseau and Manolis Papoutsakis (eds.), Transformations of Late Antiquity. Essays for Peter Brown, Farnham / Burlington, 205-222.

De Jonghe, Jean (ed.) (1837-1840), Cronijcke van den lande ende graefscepe van Vlaenderen gemaect door Nicolaes Despars, Bruges.

Justice, Steven (1994), Writing and Rebellion. England in 1381 (The New Historicism 27), Berkeley/ Los Angeles / London.

Koch, Petra (1995), “Die Archivierung kommunaler Bücher in den ober- und mittelitalienischen Städten im 13. und frühen 14. Jahrhundert”, in: Hagen Keller and Thomas Behrmann (eds.), Kommunales Schriftgut in Oberitalien. Formen, Funktionen, Überlieferung (Münstersche Mittelalter-Schriften 68), Munich.

Kras, Pawet (2014), "Libri suspecti, libri prohibiti: Wycliffite and Hussite Writings in Fifteenth-Century Polish Towns", in: Marco Mostert and Anna Adamska (eds.), Uses of the Written Word in Medieval Towns. Medieval Urban Literacy II (Utrecht Studies in Medieval Literacy 28), Turnhout, 195-226.

Krusch, Bruno/Levison, Wilhelm (eds.) (21951), Gregorii Turonensis libri historiarum X, Hannover.

Leclercq, Jean / Rochais, Henri (eds.) (1977), Sancti Bernardi opera, vol. 8: Epistolae 2: Corpus epistolarum 181-310. Epistolae extra corpus 311-547, Rome.

Lister, Martin / Dovey, Jon / Giddings, Seth / Grant, lain / Kelly, Kieran (22009), New Media. A Critical Introduction, London / New York.

Logan, Robert K. (2011), “McLuhan Misunderstood. Setting the Record Straight”, in: International Journal of McLuhan Studies 1, 27-47.

Lowe, Elias A. (1972), “Codices Rescripti. A List of the Oldest Latin Palimpsests with Stray Observations on Their Origin”, in: Ludwig Bieler (ed.), E. A. Lowe. Palaeographical Papers 1907-1965, vol. 2, Oxford, 480-519.

Manaresi, Cesare (ed.) (1958), I Placiti del "Regnum Italiae", vol. 2.2 (Fonti per la storia d'Italia 96.2), Rome.

Mauntel, Christoph (2015), “Charters, Pitchforks, and Green Seals. Written Documents between Text and Materiality in Late Medieval Revolts", in: Susanne Enderwitz and Rebecca Sauer, Communication and Materiality (Materiale Textkulturen 8), Berlin / Munich / Boston, 93-112.

Mauntel, Christoph / Sauer, Rebecca/Theis, Christoffer/Trampedach, Kai (2015), "Beschädigen und Zerstören", in: Thomas Meier, Michael R. Ott and Rebecca Sauer (eds.), Materiale Textkulturen. Konzepte - Materialien - Praktiken (Materiale Textkulturen 1), Berlin/Munich/Boston, 735-746.

McKitterick, Rosamond (2004), History and Memory in the Carolingian World, Cambridge.

McLuhan, Marshall (1964), Understanding Media. The Extensions of Man, New York.

Mente, Michael (2004), "Dominus abstulit? Vernichten und verschweigen von Schriftobjekten als kommunikativer Akt”, in: Frühmittelalterliche Studien 38, 427-447.

Menze, Volker / Akalin, Kutlu (2013/2014), “Kann man Bücher verbrennen? Severus of Antioch's Letter to Nonnus Scholasticus, a Heretical Codex, and a Late Roman Autodafé", in: Oriens Christianus 97, 1-23.

Mersiowsky, Mark (2010), "Wege zur Öffentlichkeit. Kommunikation und Medieneinsatz in der spätmittelalterlichen Stadt”, in: Stephan Albrecht (ed.), Stadtgestalt und Öffentlichkeit. Die Entstehung politischer Räume in der Stadt der Vormoderne (Veröffentlichungen des Zentralinstituts für Kunstgeschichte in München 24), Cologne/Weimar/Vienna, 13-57.

Mews, Constant J. (2002), "The Council of Sens (1141): Abelard, Bernard, and the Fear of Social Upheaval”, in: Speculum 77, 342-382.

Meyer, Johannes (ed.) (1917), Thurgauisches Urkundenbuch, vol. 2, Frauenfeld.

Migne, Jean-Paul (ed.) (1855), Patrologiae cursus completus. Series Latina 179, Paris.

Migne, Jean-Paul (ed.) (1862), Patrologiae cursus completus. Series Latina 185, Paris. 
Moeller, Charles (1913), “Les bûchers et les auto-da-fé de l'inquisition depuis le Moyen Âge”, in: Revue d'histoire ecclésiastique 14, 720-751.

Monfrin, Jacques (ed.) (1959), Abélard. Historia calamitatum, Paris.

von Mosheim, Johannes Laurentius (1790), De beghardis et beguinabus commentarius, Leipzig.

Nelis, Hubert (1927), “Burgundica II. 'Lettres cassées' de la chancellerie de Bourgogne”, in: Revue belge de philologie et d'histoire 6, 757-775.

Ong, Walter J. (1986), "Writing is a Technology that Restructures Thought”, in: Gerd Baumann (ed.), The Written Word. Literacy in Transition, Oxford, 23-50.

Ong, Walter J. (2002), Orality and Literacy. The Technologizing of the Word, London/ New York.

De Poerck, Guy (1968), “La Bible et l'activité traductrice dans les pays romans avant 1300", in: Hans Robert Jauss and Erich Köhler (eds.), Grundriss der romanischen Literaturen des Mittelalters 6 (1), Heidelberg.

Ragut, Marie-Camille (ed.) (1864), Cartulaire de Saint-Vincent de Mâcon connu sous le nom de Livre enchainé, Mâcon.

Saenger, Paul (1982), "Silent Reading: Its Impact on Late Medieval Script and Society”, in: Viator 13, 367-414.

Sarefield, Daniel (2006), “Bookburning in the Christian Roman Empire: Transforming a Pagan Rite of Purification”, in: H. A. Drake (ed.), Violence in Late Antiquity. Perceptions and Practices, Aldershot, 287-296.

Sarefield, Daniel (2007), “The Symbolics of Book Burning. The Establishment of a Christian Ritual of Persecution", in: William E. Klingshirn and Linda Safran (eds.), The Early Christian Book, Washington, 159-173.

Scalia, Guiseppe (ed.) (1999), Salimbene de Adam. Cronica, vol. 2: a. 1250-1287, Turnhout.

Sennis, Antonio (2004), "Omnia tollit aetas et cuncta tollit oblivio. Ricordi smarriti e memorie costruite nei monasteri altomedievali”, in: Bulletino dell'Istituto Storico Italiano per il Medio Evo 106, 94-138.

Sennis, Antonio (2013), “Destroying Documents in the Early Middle Ages”, in: Jonathan Jarrett and Alan Scot McKinley (eds.), Problems and Possibilities of Early Medieval Charters (International Medieval Research 19), Turnhout, 151-169.

Sickel, Theodor (ed.) (1879-1884), Die Urkunden Konrad I., Heinrich I. und Otto I., Hannover.

Sickel, Theodor (ed.) (1888-1893), Die Urkunden Otto des II. und Otto des III., Hannover.

Speyer, Wolfgang (1981), Büchervernichtung und Zensur des Geistes bei Heiden, Juden und Christen (Bibliothek des Buchwesens 7), Stuttgart.

Stevens, Wesley M. (1981), "Scientific Instruction in Early Irish Schools", in: Michael Herren (ed.), Insular Latin Studies (Papers in Medieval Studies 1), Toronto, 83-111.

Strate, Lance (2012), “The Medium and McLuhan's Message”, Razon y Palabra 80, Aug.-Oct. 2012 $<$ www.razonypalabra.org.mx> (last accessed: 11.09.2018).

Tangl, Michael (ed.) (1916), Die Briefe des heiligen Bonifatius und Lullus, Berlin.

Taylor, John / Childs, Wendy R./Watkiss, Leslie (eds.) (2003), Thomas Walsingham, The St Albans Chronicle. The Chronica Maiora of Thomas Walsingham, vol.1: 1376-1394, Oxford.

Van Leeuwen, Jacoba (2008), "Rebels, Text and Triumph: the Use of Written Documents during the Revolt of 1477 in Bruges", in: Petra Schulte, Marco Mostert and Irene van Renswoude (eds.), Strategies of Writing. Studies on Text and Trust in the Middle Ages (Utrecht Studies in Medieval Literacy 13), Turnhout, 301-322.

Verdeyen, Paul (1985), "Le procès d'inquisition contre Marguerite Porete et Guiard de Cressonessart (1309-1310)”, in: Revue d'histoire ecclésiastique 81, 47-94.

Walker, Rose (1998), Views of Transition. Liturgy and Illumination in Medieval Spain, London.

Weber, Christoph Friedrich (2014), "Trust, Secrecy, and Control in the Medieval Italian Communes", in: Marco Mostert and Anna Adamska (eds.), Writing and the Administration of Medieval Towns. Medieval Urban Literacy I (Utrecht Studies in Medieval Literacy 27), Turnhout, 243-265. 
Werner, Thomas (1995), “Vernichtet und vergessen? Bücherverbrennungen im Mittelalter”, in: Otto Gerhard Oexle (ed.), Memoria als Kultur (Veröffentlichungen des Max-Planck-Instituts für Geschichte 121), Göttingen, 149-184.

Werner, Thomas (2007), Den Irrtum liquidieren. Bücherverbrennungen im Mittelalter (Veröffentlichungen des Max-Planck-Instituts für Geschichte 225), Göttingen.

Worm, Peter (2008), "From Subscription to Seal: The Growing Importance of Seals as Signs of Authenticity in Early Medieval Royal Charters", in: Petra Schulte, Marco Mostert and Irene van Renswoude (eds.), Strategies of Writing. Studies on Text and Trust in the Middle Ages (Utrecht Studies in Medieval Literacy 13), Turnhout, 63-83. 
